\title{
ANALISIS PENENTUAN PENDAPATAN LABA PADA USAHA DAUR ULANG LIMBAH AN-ORGANIK PADA BANK SAMPAH
}

\author{
Lindawati ${ }^{1}$, Anggun Anggraini ${ }^{2}$, Indawati ${ }^{3}$, Wulandari Cahyani Putri ${ }^{4}$, \\ Prodi Akuntansi S1, Fakultas Ekonomi, Universitas Pamulang \\ Email : dosen02248@unpam.ac.id ${ }^{1}$,dosen02156@unpam.ac.id ${ }^{2}$,dosen02151@unpam.ac.id ${ }^{3}$, \\ dosen02274@unpam.ac.id ${ }^{4}$
}

\begin{abstract}
Abstrak
Tujuan dari Kegiatan Pengabdian Kepada Masyarakat adalah untuk melaksanakan salah satu Tri Dharma Perguruan Tinggi. Selain itu diharapkan dengan pengabdian kepada masyarakat tersebut keberadaan perguruan tinggi dapat memberikan kontribusi besar kepada pengembangan dan penerapan keilmuan kepada masyarakat. Metode yang digunakan pada Pengabdian Kepada Masyarakat ini berupa ekspositori yaitu penyampaian materi secara verbal dan inquiry yaitu pembelajaran yang menekankan pada proses berpikir kritis dan analitis terkait keilmuan akuntansi dan manajemen pemasaran dengan pemahaman mendalam terkait materi bagaimana menentukan masa depan. Hasil pengabdian masyarakat yang diperoleh adalah bertambahnya keilmuan bagi para anggota dan ketua Bank Sampah Griya Asri Pamulang, terutama dilihat dari segi menghitung nilai pendapatan dimulai dari menghitung biaya produksi sampai dengan harga pokok dari produk tersebut, selain itu dari memanfaatkan limbah sampah tersebut, diharapkan mereka lebih bisa mengubah paradigma masyarakat untuk memaknai sampah sebagai sesuatu yang mempunyai nilai untuk dimanfaatkan kembali sekaligus mengurangi jumlah sampah nasional. Pada bank sampah, sampah organik akan didaur ulang menjadi kompos. Sementara sampah non-organik akan diolah kembali agar bisa bermanfaat secara ekonomis. Pembangunan bank sampah, juga dapat menjadi momentum untuk membina kesadaran kolektif masyarakat untuk memulai memilah, mendaur ulang, dan memanfaatkan sampah, karena sampah ternyata mempunyai nilai jual yang cukup baik.
\end{abstract}

Kata kunci: Pendapatan Laba, Limbah Daur Ulang.

\section{Abstract}

The purpose of Community Service Activities is to carry out one of the Tri Darma of Higher Education. In addition, it is expected that through community service, the existence of higher education institutions can make a major contribution to the development and application of knowledge to the community. The method used in this Community Service is expository namely the delivery of material verbally and inquiry that is learning that emphasizes the process of critical and analytical thinking related to accounting and marketing management with a deep understanding of the material on how to determine the future. The results of community service obtained are increased knowledge for members and leaders of the Griya Asri Pamulang Garbage Bank, especially in terms of calculating the value of income starting from calculating the cost of production up to the cost of the product, in addition to utilizing the waste, it is expected that they will be more can change the community paradigm to interpret waste as 
something that has value to be reused while reducing the amount of national waste. At the garbage bank, organic waste will be recycled into compost. While non-organic waste will be reprocessed so that it can be economically useful. The construction of a garbage bank can also be a momentum to foster community collective awareness to start sorting, recycling, and utilizing waste, because waste has a fairly good sale value.

Keywords: Porfit Revenue, Recycle.

\section{PENDAHULUAN}

Pembelajaran berbasis kewirausahaan yang menerapkan prinsip-prinsip dan metodologi ke arah aplikasi kewirausahaan melalui kreatifitas dan inovasi (Syahbrudin, 2019), begitupun dalam usaha pemilahan sampah yang merupakan serangkaian kegiatan berkesinambungan dan menyeluruh mencakup pengurangan dan penanganan sampah diharapkan dapat mencetak entrepreneur yang menciptakan inovasi dan kreasi dari barang-barang yang sudah tidak berguna bagi kebanyakan orang. Pengurangan sampah meliputi pembatasan timbunan sampah, pendauran ulang sampah dan atau pemanfaatan kembali sampah (PP 81, 2012). Selain itu sampah juga memiliki nilai ekonomis jika dilakukan daur ulang sampah. Program bank sampah adalah program yang mengajak masyarakat untuk memilah sampah organik dan non-organik untuk ditukarkan menggunakan uang pada bank-bank sampah yang telah tersebar di 34 provinsi di Indonesia. Namun, ada juga bank sampah yang menerapkan penukaran sampah untuk pembayaran listrik, pembelian sembako, pembayaran biaya kesehatan, dan mendapatkan emas. Program bank sampah itu bisa mengubah paradigma masyarakat untuk memaknai sampah sebagai sesuatu yang mempunyai nilai untuk dimanfaatkan kembali sekaligus mengurangi jumlah sampah nasional (Rini, 2019). Partisipasi masyarakat sangat dibutuhkan dalam pengelolaan sampah. cara menentukan pendapatan laba pada usaha daur ulangan organic, di antaranya; pentingnya pengetahuan dasar tentang perhitungan harga pokok terhadap produk anorganik bank sampah, pentingnya pengetahuan dasar tentang pendapatan laba terhadap penjualan produk anorganik bank sampah. Sedangkan tujuan dari pengabdian pada masyarakat di antaranya; membantu memberikan pengetahuan tentang tentang perhitungan harga pokok terhadap produk anorganik bank sampah., membantu memberikan pengetahuan tentang perhitungan 
pendapatan laba terhadap produk anorganik bank sampah.

Menurut penelitian terdahulu yang dilakukan oleh Dian Rini Beutari dan Laelisneni (2017) dengan judul “Analisis Penetapan Harga Jual dalam Perencanaan Laba pada Home Industry Tempe Setia Budi Medan” menyimpulkan bahwa penentuan harga jual ditetapkan berdasarkan harga yang ada di pasar.

\section{METODE}

Masalah sampah yang dihadapi Griya Asri Pamulang, terutama akibat banyaknya masyarakat yang kurang peduli dengan lingkungan. Kegiatan dilakukan pada Lokasi Pengabdian Masyarakat di Jl. Inpres Perum Griya Pamulang Asri RT 006/009 Benda Baru Pamulang Tangerang Selatan, Pelakasanaan Pengabdian dimulai tanggal 17-19 Oktober 2019 dalam Jangka Waktu Pengabdian 3 (tiga) hari. Peserta ceramah terdiri dari 20 orang, dari anggota bank sampah Griya Asri Pamulang, dan ibu rumah tangga yang terlibat langsung dalam pengelolaan sampah rumah tangga dan usaha.pengabdian masyarakat FE Unpam, pemaparan materi ceramah, kunjungan lapangan ke tempat pemilahan sampah, pembuatan pupuk organik, hingga tempat penimbangan sampah platik, kertas atau logam yang diterima. Setelah kunjungan lapangan, acara dilanjutkan dengan diskusi. Metode yang cocok digunakan dalam melaksanakan kegiatan tersebut agar lebih efektif dalam mencapai tujuan adalah sosialisasi penentuan pendapatan laba dan kunjungan lapangan mengenai bagaimana sistem bank sampah tersebut terbentuk.

\section{HASIL DAN PEMBAHASAN}

Mekanisme Pengelolaan sampah: Mekanisme pengelolaan sampah dengan penerapan extended producer responsibility yang merupakan strategi yang didisain dalam upaya mengintegrasikan biaya lingkungan ke dalam seluruh proses produksi suatu barang sampai produk itu tidak dapat dipakai lagi sehingga biaya lingkungan menjadi bagian dari komponen harga pasar produk tersebut. mekanisme pengelolaan sampah di Bank Sampah Griya Asri antara lain; Nasabah mempunyai sampah rumah tangga yang akan di tabung di Bank Sampah Griya Asri. melakukan pemilahan dan pembersihan sampah yang nantinya akan dibawa ke Bank Sampah pemilihan dilakukan dengan cara memisahkan sampah berdasarkan jenisnya. Karena setiap sampah memiliki harga yang berbeda-beda. 
Sampah yang telah dipilah ditimbang oleh petugas bank sampah griya asri berdasarkan jenisnya. setiap sampah memiliki harga yang berbeda berdasarkan jenisnya.

Hasil timbangan sampah dicatat dalam buku milik petugas Bank Sampah Griya Asri dan buku tabungan milik nasabah yang didalamnya berupa pencatatan jumlah uang yang didapat oleh nasabah. Sampah dari nasabah di simpan dalam gudang penyimpanan Bank Sampah Griya Asri.

Kumpulan sampah dari nasabah yang terkumpul akan diambil untuk didaur ulang oleh bank sampah sesuai kebutuhan. Sampah yang tidak memungkinkan untuk didaur ulang akan dijual ke pengepul. Hasil daur ulang bank sampah di pasarkan dan dijual untuk umum. Sehingga sampah kembali digunakan oleh masyarakat.

Berikut adalah skema tentang daur ulang sampah dapat dilihat pada gambar 1 sebagai berikut:

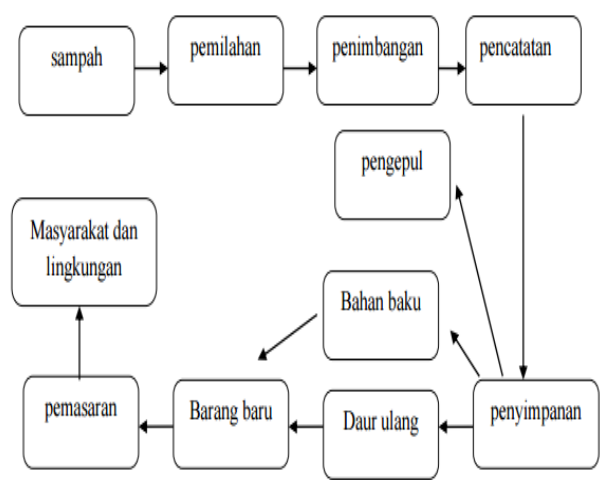

Gambar 1.1

\section{Proses Daur Ulang Sampah}

Harga sampah yang ada di bank sampah dapat setiap saat berubah. Ini dikarenakan sampah pada harga pasaran tidak statis. Naik turunnya harga biasannya mengikuti harga pengepul pada umumnya.Bank Sampah Griya Asri mengajak serta menawarkan kepada masyarakat sebuah kerjasama untuk mengelola sampah organik bersama-sama. Kerjasama tersebut berupa pihak bank sampah menyediakan tong-tong untuk pengomposan warga yang memang bersedia untuk melakukan pengomposan dipersilahkan mengisi tong-tong tersebut. Hasil pengomposan tersebut dapat dijual atau digunakan dengan pembangian hasil $60 \%$ untuk warga yang mengisi serta merawat tong dan $40 \%$ untuk bank sampah.

Sampah-sampah yang telah terkumpul di Bank Sampah Griya Asri akan didaur ulang olah pihak bank sampah hasil daur ulang sampah tersebut nantinya akan dibagi untuk anggota bank sampah (pengurus). Harga kreasi dari bank sampah sangat beragam, tergantung dari bahan baku jenis dan proses pembuatan barang tersebut. Adapun rincian harta hasil kreasi daur ulang sampah sebagai berikut : 
Tabel 1.1 Hasil Kreasi Daur Ulang

\begin{tabular}{|c|c|c|}
\hline No & Nama Barang & Harga Perunit \\
\hline 1 & Dompet S, L, XL & $\begin{array}{l}\mathrm{Rp} \quad 25.000 \\
50.000\end{array}$ \\
\hline 2 & $\begin{array}{l}\text { Tas bungkus kopi dan } \\
\text { sejenisnya kecil }\end{array}$ & $\begin{array}{l}\mathrm{Rp} \quad 70.000 \\
100.000\end{array}$ \\
\hline 3 & $\begin{array}{l}\text { Tas bungkus kopi dan } \\
\text { sejenisnya sedang }\end{array}$ & $\begin{array}{l}\text { Rp } \quad 85.000 \\
130.000\end{array}$ \\
\hline 4 & $\begin{array}{l}\text { Tas bungkus kopi dan } \\
\text { sejenisnya besar }\end{array}$ & $\begin{array}{l}\mathrm{Rp} \quad 90.000 \\
150.000\end{array}$ \\
\hline 5 & Bingkai & Rp 70.000 \\
\hline 6 & Tempat pensil jahit & $\begin{array}{l}\text { Rp } \quad 6.000 \\
10.000\end{array}$ \\
\hline 7 & Bros & $\begin{array}{l}\text { Rp } 5.000 \\
20.000\end{array}$ \\
\hline
\end{tabular}

Hasil produk bank sampah dipasarkan dengan mengikuti event-event mengenai kegiatan yang berhubungan dengan kreasi masyarakat dan pengelolaan sampah. Baik itu event dari dinas atau dari umum. Hal ini merupakan salah satu cara untuk meningkatkan nilai ekonomis dari barang tersebut.

Peran Bank Sampah Griya Asri Dalam Menghasilkan Pendapatan dan Pemberdayaan Masyarakat dapat terlihat pada dampak yang dihasilkan. Ada dua dampak menojol yang dihasilkan oleh Bank Sampah Griya Asri terhadap masyarakat yaitu :

\section{Dampak ekonomi masyarakat}

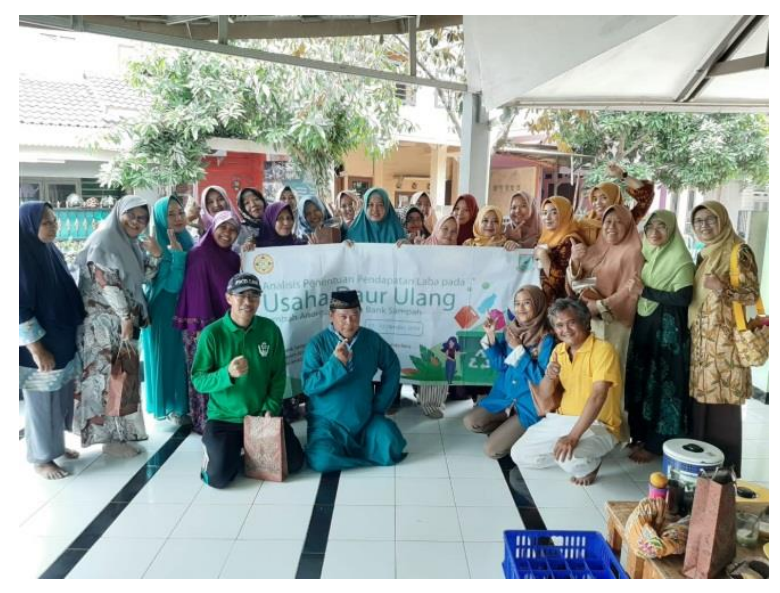

Bank Sampah Griya Asri merupakan sebuah kelompok masyarakat yang bertujuan unnuk memberdayakan serta meningkatkan perekonomian masyarakat dengan cara memanfaatkan sampah sebagai salah satu sumber pendapatan. Selain sebagai sumber pedapatan dengan adaanya Bank Sampah Griya Asri dapat mengurangi masalah sampah yang ada di Tangerang Selatan khususnya Griya Asri pamulang.

Bank Sampah Griya Asri telah mengubah persepsi bahwa sampah adalah barang yang tidak berguna bisa menjadi sesuatu yang bernilai ekonomis. Hal ini telah menarik masyarakat untuk bergabung dalam kegiatan yang dilakukan oleh Bank Sampah Griya Asri baik dengan mengumpulkan sampah untuk disetorkan ataupun terlibat langsung dalam proses pengelolaan sampah (daur ulang). Pemberdayaan yang dilakukan bank sampah terhadap masyarakat hasilnya adalah tentang bagaimana bank sampah 
dapat meningkatkan pendapatan yang ada di masyarakat sehingga dapat memenuhi kebutuhan mereka. Masyarakat yang menjadi anggota Bank Sampah Griya Asri telah mendapatkan dampak berupa peningkatan pendapatan. Dampak yang dihasilkan setiap anggota berbeda, tergantung partisipasi yang dilakukan anggota sendiri terbagi menjadi yaitu :.

\section{Nasabah}

Peran bank sampah terhadap peningkatan pendapatan nasabah bisa dikatakan masih kurang, hal ini dikarenakan sampah yang ditabung merupakan sampah rumah tangga milik pribadi dalam waktu satu tahun (tahun 2018 sebelum Hari Raya Idul Fitri), nasabah yang hasil tabungannya paling banyak biasanya penabung merupakan pemilik kantin sekolahan (kantin sekolahan menghasilkan sampah lebih banyak ketimbang rumah tangga pada umumnya). Sedangkan untuk hasil tabungan pada bank yang tabungannya paling sedikit biasanya dikumpulkan dari sampah rumah tangga milik pribadi.

Dari program-program Bank Sampah Griya Asri yang telah dijelaskan sebelumnya, telah memberikan dampak ekonomi bagi masyarakat yang ikut terlibat di dalamnya, yaitu meningkatkan pendapatan. Karena ini merupakan tujuan bank sampah. Walaupun tidak secara signifikan nilainya, tapi bank sampah sudah mampu dalam meningkatkan pendapatan nasabahnya. Sampah yang dulu hanya bisa dibuang dan memenuhi tempat sampah, sekarang bisa diolah oleh masyarakat untuk mendapatkan pundi-pundi rupiah. Sebagai contoh :

Jumlah rata-rata penghasilan nasabah dari bank sampah setiap bulan $=$

Jumlah rata-rata tabungan sampah / nasabah $=29.250 .000 / 65=450.000$

Dari perhitungan di atas, kita bisa ketahui jumlah rata-rata tabungan sampah nasabah adalah 450.000 /nasabah setiap bulannya.

\section{Pengrajin}

Peran bank sampah terhadap peningkatan pendapatan pengrajin bisa dikatakan cukup berhasil hal ini terlihat dari upah atau balas jasa yang ditawarkan oleh bank sampah terhadap para pengrajin untuk rincian upah pengrajin sebagai berikut : 1) Cuci bungkus kopi dan sejenisnya:5000/ kg .2) Cuci bungkus minyak dan sejenisnya : 600/kg, 3) Cacahan : 10.000/kg , 4) Jahit harian : 25.000/ hari, 5) Borongan : 1.000 s/d 10.000 tergantung kreasi yang di buat, 6) Nganyam 3.500/100 bks, 7) Jahit anyaman : 2 000/100 bks

Dari upah tersebut pengrajin bisa 
mendapatkan peghasilan 500.000-700.000 rupiah perbulan, namun jika ada pesanan yang banyak dari pembeli pengrajin bisa mendapatkan penghasilan $\quad 1.000 .000$ perbulan.

\section{Pengurus}

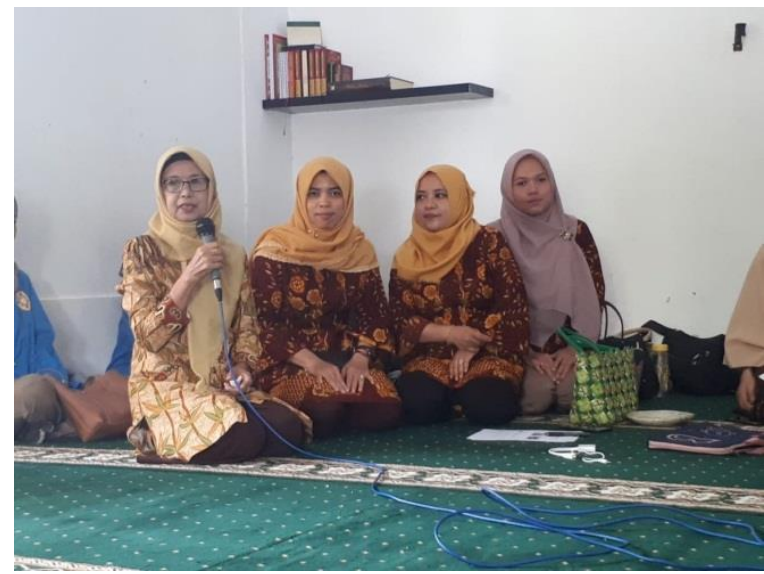

Peran bank sampah terhadap peningkatan pendapatan pengurus terlihat cukup berhasil. Pengurus tidak mengambil keuntungan dari tabungan sampah. Namun pengurus mengambil keuntungan dari hasil penjualan barang kreasi. Omzet penjualan barang kreasi setiap bulannya bisa mencapai Rp 9.000.000 setelah dikurangi pengeluaran menjadikan pendapatan bersih bank sampah sampai Rp 5.000.000 perbulannya. Hasil ini nantinya akan dibagi kesemua pengurus.

\section{Dampak sosial masyarakat}

Selain berperan dalam pengerak ekonomi masyarakat, bank sampah juga berperan dalam sosial. Adapun dampak sosial masyarakat yang timbul akibat dari adanya Bank Sampah Griya Asri yaitu meningkatkan kepedulian masyarakat terhadap lingkungan. Memang awalnya masyarakat diiming-imingi pendapatan dengan menjadi anggota nasabah bank sampah, namun sekarang masyarakat mulai sadar akn pentingnya menjaga lingkungan. Karena masyarakat telah merasakan dampaknya secara langsung. Masyarakat mulai sadar dan mulai tidak membuang sampah di sembarang tempat, terutama pada sungai dan saluran/drainase. Dilihat dari kualitas kesehatan, bagi masyarakat Sampah merupakan salah satu sumber penyakit. ketika salah satu sumber penyakit tersebut mulai terkelola sehingga berkurang bahkan tidak ada. Maka tentunya kualitas kesehatan masyarakat yang ada di sekitar Bank Sampah Griya Asri akan meningkat.

Tujuan akhir pemberdayaan adalah adanya peningkatan pendapatan Indikator keberhasilan pemberdayaan masyarakat sebagai sebuah proses seringkali diambil dari tujuan sebuah pemberdayaan yang menunjukan pada keadaan atau hasil yang ingin dicapai oleh sebuah perubahan sosial.

\section{KESIMPULAN}

Pelaksanaan kegiatan Pengabdian Kepada Masyarakat yang dilakukan oleh dosen-dosen program studi Akuntansi telah berjalan dengan lancar dan mendapat 
sambutan hangat dari tempat pelaksanaan kegiatan ini yaitu Bank Sampah Griya Asri Indonesia Jl. Inpres Perum Griya Pamulang Asri RT 006/009 Benda Baru Pamulang Tangerang Selatan. Dengan diadakannya program Pengabdian Kepada Masyarakat ini, pengurus dan masyarakat sekitar, dapat menjalankan program untuk memasarkan dengan harga jual yang lebih efektif. Sehingga dari sampah yang tadinya terbuang akan menghasilkan keuntungan dan membantu perekonomian rumah tangga warga sekitar.

\section{REFERENSI}

Aryenti, (2011), PeningkatanPeran Serta Masyarakat Melalui Gerakan Menabung Pada Bank Sampah Di Kelurahan Babakan Surabaya, Kiaracondong Bandung, Pusat Litbang Pemukiman, Bandung

Beutari Rini dan Laelisnaeni. (2016). Analisis Penetapan Harga Jual dan Perencanaan Laba Pada Home Industri Tempe Setia Budi Medan. Jurnal Bisnis Administrasi. Politeknik LP31 Medan.

MukonoHJ.(2006) Prinsip Dasar Kesehatan

Lingkungan Surabaya : Airlangga

University Press;.

Mulyadi (2012) Akuntansi Biaya, Jakarta : Sekolah Tinggi Ilmu Manajemen YKPN.

Notoatmodjo, Soekidjo. (2003). Pengembangan Sumber Daya
Manusia, Jakarta: PT. Rineka Cipta.

Pemerintah Indonesia. Undang-undang No.81 Tahun 2012 tentang Pengelolaan Sampah Rumah Tangga dan Sampah Sejenis. Lembaran Negara RI Tahun 2012. Sekretariat Negara. Jakarta.

Pemerintah Indonesia. Undang-undang Nomor 32 Tahun 2009 Tentang Perlindungan dan Pengelolaan Lingkungan Hidup. Lembaran Negara RI Tahun 2012. Sekretariat Negara. Jakarta.

Ritzer, George-Douglas J. Goodman. (2007) Teori Sosiologi Modern. Jakarta : Kencana Predana Media Group.

Septiowati, Rini., Oktavianna, Rakhmawati., \& Saputri, Sevty Wahiddirani (2019) Pemanfaatan Minyak Jelantah Menjadi Sabun Cuci Pada Bank SAmpah Di Kelurahan Bambu Apus Pamulang. ABDIMISI Vol.1 No.1 Desember 2019.

Slamet J.S. (2009) Kesehatan Lingkungan. Yogyakarta: Gajah Mada University Press.

Soekanto, Soerjono. (2004) Sosiologi Keluarga. Rineka Cipta. Jakarta.

Sujarweni V. Wiratna. (2015) Akuntansi Manajemen Teori dan Aplikasi. Yogyakarta : Pustaka Baru Press.

Syahbrudin, Johan.,Prasetya, EkaRima., \& Mundiroh, Siti. (2019). Pengaruh Pendekatan Pembelajaran Bahasa Inggris dan Berhitung Berbasis Kewirausahaan Terhadap Minat Berwirausaha Bagi Anak Panti Asuhan Al Kamilah. ABDIMISI Vol.1 No.1 Desember 2019. 